\title{
Government communication about policy intentions: Unwanted propaganda or democratic inevitability? Surveys among government communication professionals and journalists in Belgium and the Netherlands
}

Dave Gelders, Rozane De Cock, Peter Neijens and Keith Roe

\section{Abstract}

Recent developments in politics, the media, and society have stressed the rising importance of public communication from the government about policies not yet been adopted by Parliament. Government communication professionals and journalists are key figures in this process but conflicting interests mark a tense relationship. Up until now, few empirical studies have been conducted to shed light on the opinions of both professions concerning 'Communication about Not yet Adopted Policy' (CNAP). We studied the issue in both the Netherlands and Belgium because research has shown that these countries stand out in regard to debating and reflecting on CNAP. This article maps recent Dutch empirical research and a more elaborated Belgian study, and shows that CNAP is generally accepted by government communication professionals and journalists. Moreover, the Belgian study shows the respondents' opinions regarding the acceptance of CNAP, their arguments, and the conditions CNAP must meet.

Keywords: public communication, public relations, journalism, policy intentions, propaganda

\section{Introduction}

Communication from a minister of the government about parliamentary not yet adopted policies (CNAP) is considered important as well as delicate or controversial. This kind of policy communication is important because it allows for citizens and organizations to be informed about policy intentions and thus more involved in the policy-making process. But at the same time, CNAP is also delicate because of a fear of state propaganda and confusion among citizens and organizations regarding policy intentions on the one hand and real decisions on the other. This confusion could be the result of the fact that the government communi- 
cates about yet unadopted policies, and/or because the government does so in an incomplete and inconsistent way (Gelders, 2005a).

There are some relatively recent developments in citizenry, politics, and media which clearly indicate that such a preliminary information provision is a highly relevant and delicate issue that merits close consideration. We will commence by noting some of the most important and relevant developments.

First, a dissolution of political attitudes and affiliations previously thought to be strong anchors (Blumler and Gurevitch, 1995); i. e., the voting behavior of the citizenry is less predictable and the citizenry is more demanding. Politicians and political parties are involved in permanent campaigning (Norris, 2000) during which the techniques of spin doctoring, opinion polls, and professional media management are increasingly applied to routine everyday politics. Furthermore, it has become common practice to float trial balloons in order to uncover if the policy intentions will be accepted and appreciated by the public. Using the argument that the policymaking process should be less secretive and more transparent to the public, today's politicians often freely discuss their policy intentions before the eyes of the camera.

Second, interpretive reporting is nearly as old as journalism itself but has only recently become the dominant model of news coverage, which means that reporters question politicians' actions and commonly attribute strategic intentions to them, giving politicians less chance to speak for themselves (Patterson, 1996). Striving for a story, the media do not always give the complete picture or exact status of policy issues (i.e., is it about a policy intention or a policy decision?). Consciously or not, the media supply biased information to citizens whose reactions to policy decisions and policymakers are based on what the media choose to communicate and the manner in which they communicate it. This can influence the probability that the policy measure will be adopted and implemented successfully (Cobb and Elder, 1981).

Specifically, the use by the government or a minister of paid publicity (leaflets, newspapers advertisements etc.) about not yet adopted policies has been brought into question in several countries. The specific executive position of a minister may cast a shadow over the exact aim of the message. Is it (personal, political) propaganda and therefore a misuse of public money? Or is it supplying transparent information in a democratic state aimed at informing and involving citizens and societal organizations regarding the formation of a policy? These questions were raised in the campaign regarding reform of the Post Office in the United States (Linsky, 1986). Leaflets on Operation Rescue and Paying for local Government: the Need for Change did the same in the United Kingdom (Scammell, 1999) whereas the trial balloons on social security brought 
CNAP under discussion in Germany (Jarren as cited in Meyer, 2002). Other pre-eminent examples include the dissemination of leaflets on the introduction of toll-roads by the Dutch Government (Kranendonk, 2003) and the dissemination of leaflets on drug policy in Belgium (Gelders, 2005b).

In this article we will examine what the professionals involved - government communication professionals and journalists - think about this kind of government communication in Belgium and the Netherlands. We ask for their general opinion towards the allowance of CNAP, as well as for the pros and the cons and the conditions the professionals consider to be important when judging the allowance of CNAP.

An international comparative study by Gelders (2005b) shows that the Netherlands and Belgium stand out when it comes to debating and reflecting on CNAP. In the Netherlands, the discussion about proper public communication about policies started after World War II, but whereas influencing public opinion was strictly limited to policies already accepted by Parliament, the opinion towards CNAP relaxed during the last few years. Based on expert advice from the Commission on Future Government Communication (CTO) (2002), present government policy marks a turning point in this debate. At the core lies the idea that government PR is an interactive process that starts at the beginning of the policy cycle: "communication is increasingly less concerned with only the translation after policy has been chosen, and ought to take place in the heart of the policy process" (CTO, 2002). The reasoning is that public debate begins with the announcement of policy proposals and that government PR should contribute to that debate throughout the process. The Committee states that:

The citizen has the right to know the content of the government's intentions and its motives. The citizen gets a lot of contrary information via news and paid information by the critics of the government's policy. So, it is absolutely reasonable that the government can also use all the information channels in the formulation stage of policy making (CTO 2002; translated).

In Belgium, the discussion is more recent. The Code of good practice on behalf of the communication campaigns of The Flanders Authority ${ }^{1}$ stipulates that mass media campaigns are only allowed if they are aimed at stimulating citizens to participate in societal debates and to improve interactive policymaking. The government is obliged to clearly communicate the successive steps in the policymaking process and from whose point of view the campaign is presented. Completeness, timeliness, and factuality of public information are three key parameters in this guideline. 


\section{Background}

To governments, the relationship with journalism is crucial; the battle for the public's trust increasingly takes place through the media rather than in the parliament. The news media are a platform where the government establishes or loses its credibility. The perceived importance of media for government has led to a tremendous growth of communication departments at ministries and has fuelled further professionalization of the government PR profession. This means that an ever-increasing number of PR practitioners and other media strategists use the media to try to influence the formation of opinions and the decision-making process on a daily basis. Spin doctoring and news management have become key concepts in this process (Brants, 2000).

At the same time, there have been significant developments in the media as well. The explosive growth in media supply has resulted in increased competition between journalists and an intense contest to 'make the news'. The attention of the media has shifted from content to incidents, controversies, quarrels, and the exploitation of emotions (McChesney, 1999; Brants, 2000). Rolling cameras, open microphones, and ambush tactics are weapons in the struggle. The competition is fierce, and so are the emotions. Journalists constitute more and more an independent power in society (Swanson and Mancini, 1996; Brants, 2000) and politicians adapt greatly to the media logic (Mazzoleni and Schulz, 1999). The relationship between journalists and politicians is characterized as one of mutual distrust, which leads to negative and cynical reporting about politics that contribute to a diminishing trust at the side of the electorate (Patterson, 1993; Cappella and Jamieson, 1997).

In respect to the role perceptions of journalists, and government PR people we draw on two recent studies. The first study (Deuze, 2002) compared the opinions of journalists in five countries (Australia, Germany, United States, Great Britain, and the Netherlands) and concluded that journalists in Western democracies perceive their role in largely similar terms (see also: Delano and Henningham, 1995; Weischenberg, Loeffelholz, and Scholl 1998; Henningham, 1996). The journalists judged the three classical pillars of journalism as the most important: to interpret, to get the news to the public quickly, and to investigate claims and announcements made by companies and government. Deuze's study also identified a fourth function of journalists: namely, to provide relaxation and entertainment.

The second study (Neijens, 2002) studied role perceptions of government PR people in the Netherlands and found that providing information (giving information about policies, provisions, products, and services of the government) was considered very important. Influencing, 
such as promoting an adequate image or support for the policy of the government, was debated and evaluated as 'rather' important on average.

Research from several countries acknowledged the tense relationship between journalists and government communication professionals (Stegall and Sanders, 1986; Stappers and Nillesen, 1985; Van Ruler, 1995; Delorme and Fedler, 2003). Conflicting roles, role confusion, and stereotyping are central themes in their mutual job descriptions. In general, researchers stress that journalists have more negative opinions about PR practitioners than vice versa. "It seems that journalists relegate PR practitioners to a lower status not only because of perceived poorer job performance and lower ethical conduct, but also because they perceive PR practitioners to have less honourable intentions" (Stegall and Sanders, 1986: 347). While they have conflicting interests, interdependence and the need for close cooperation mark their complex relationship. In line with these earlier studies, more recent work from Jempson (2005) notes that PR professionals are calling for a rethink on the relationship between both professions since their credibility and public trust appear to be eroding.

Remarkably, only a handful of scholars have touched on the topic of government communication about policy intentions by questioning either one or the other profession about CNAP, and they did so in a limited manner. Stappers and Nillesen (1985) asked Dutch government PR officials whether it was acceptable to influence behavior when policy is not yet adopted. Only $10 \%$ of them agreed. Research by Stappers and Nillesen is the only empirical study on CNAP and it was conducted twenty years ago. More recent data were available thanks to Neijens' study. Neijens (2002) questioned a large-scale group of Dutch government communication professionals and journalists using a mail questionnaire. In the Belgian studies political journalists were questioned by an Internet survey (Lahousse, 2005), and government communication professionals were interviewed in face-to-face interviews (Gelders, 2005a). This article will map all the relevant data from both countries, and compare them where possible.

\section{Research questions}

Our first two research questions deal with the data in the Netherlands and Belgium, whereas the two last questions deal with the Belgian situation as a more elaborated questionnaire on CNAP was conducted in Belgium.

RQ 1: What is the general opinion of Belgian and Dutch journalists and government communication professionals on CNAP? 
RQ 2: To what extent do opinions of journalists and government communication professionals differ within each country (within the Netherlands, within Belgium)?

To what extent do opinions of journalists differ between both countries?

To what extent do opinions of government communication professionals differ between both countries?

RQ 3: What pros and cons do Belgian journalists and government communication professionals put forward concerning CNAP and how do these arguments correlate with the general opinion on CNAP?

RQ 4: What are the most important criteria CNAP has to meet according to Belgian journalists and government communication professionals? Do they prescribe different preconditions?

\section{Questionnaire items}

The Dutch as well as the Belgian research examined the general opinion towards CNAP. More specific data on the vision of journalists and government communication professionals are (only) available in Belgium. We asked the Belgian professionals which pros and contras and which conditions they consider to be important while judging the allowance of CNAP.

\section{Data collection}

Neijens (2002) sent a mail questionnaire to a sample of journalists and government communication professionals in the Netherlands. Lists of names and addresses were gathered from the Handbook for the Press and three professional associations. The response rates were $51 \%(\mathrm{~N}=363)$ for the government communication professionals, and $28 \%(\mathrm{~N}=126)$ for the journalists, which are common rates for mail questionnaires sent to individuals by name. The profile of both groups of participants corresponded to the profile as presented in other studies by Deuze (2002) and Van Ruler (1996). Almost three quarters of the journalists were male in contrast to only half of the people employed in government communication functions. More than $90 \%$ of the professionals had completed higher education ( $49 \%$ university, $43 \%$ non-university). The average age of the government communication professionals was 42 and for journalists 38 . The journalists in the study worked for newspapers, weekly magazines, radio, and television.

Gelders (2006) conducted 32 semi-structured face-to-face interviews among government communication professionals at the Belgian Federal 
and Flemish level. A total of 32 out of 36 contacted government communication professionals were willing to participate in the study, a high response rate of $89 \%$. In total, $72 \%$ of the interviewees were male, three quarters obtained a university degree, and the average age was 39. By comparing this profile to the outcome of other studies among government professionals, one can conclude that there is no reason to assume that our results would be distorted (Suetens and Walgrave, 1999; Brans and Hondeghem, 1999).

Lahousse used a comparable questionnaire as Gelders, but she made the survey available through an email distributed among all Belgian political journalists listed in the database of the Flemish Association of Journalists (VVJ, Belgium as of April 2005) $(\mathrm{N}=109)$. After personal contact by telephone and a reminder note by e-mail, 55 journalists sent in their questionnaire and response rate rose to $50.5 \%$, which is high for an Internet survey (Cook, Heath, and Thompson, 2000). Lahousse considered an electronic (Internet) survey most appropriate as journalists generally have Internet access and an email address, and as they have to meet several deadlines. In her sample, $78 \%$ of the political journalists were male with an average age of 43 and $80 \%$ of the reporters held a university degree. The journalists who participated in this study (see Neijens), worked for different types of media. These results are also in line with larger-scale Belgian studies conducted by De Bens, De Clercq and Paulussen (2003).

It is not useful to either statistically compare the data between the Netherlands and Belgium or within the Belgian professions as the Belgian studies deal with a relatively small number of communicators.

\section{Results}

In the presentation of the results we will follow the research questions mentioned above.

\section{Concerning the Netherlands and Belgium (RQ1-RQ2): General opinion towards CNAP}

The professionals in both countries who participated in our study (both government communication professionals as well as journalists) are generally positive towards CNAP. Three quarters of the Belgian journalists held a positive or even a very positive view of this form of communication. Remarkably, their opinion is shared by both the Belgian and the Dutch government communication professionals ( $74 \%$ and $81 \%$ respectively). The Dutch journalists are negative about the use of CNAP to stimulate public support for policy intentions: only $37 \%$ of them agreed. 


\section{Concerning Belgium (RQ3): Arguments for and against CNAP}

Regarding the pros, almost three quarters of Belgian journalists consider CNAP a worthwhile method because it keeps citizens from being presented with a fait accompli. The results show that $78.2 \%$ of Belgian government communication professionals indicate on a four item scale that they are positive or even very positive about this statement. A significant difference between both professions is found with regard to the statement: 'CNAP from ministers is good because in this way government can counterbalance the impact of the media'. Only a fifth of Belgian reporters agree with this statement whereas $65.8 \%$ of the government communication professionals do so.

Regarding the cons, the opinions of Belgian journalists and government communication professionals were considerably divided. First, although the general opinion on CNAP is positive (see above), $72.7 \%$ of the journalists were opposed to CNAP from ministers as this creates false expectations among citizens. Government communication professionals hold a less stringent opinion: $56.3 \%$ agree. Nevertheless, this counter argument is often used in the public debate about CNAP. Second, Belgian journalists are twice as likely than government communication professionals $(49.1 \%$ and $25.1 \%$ respectively) to agree with the argument that CNAP is a waste of time and money because the plan might never be implemented. The results of the face-to-face interviews point out that government communication professionals see a remarkable difference between mass media campaigns that imply direct and large-scale costs and the so called 'free' intervention of the press. Although an article in a newspaper or an interview on television does not directly affect the government budget, media attention can lead to considerable indirect costs due to extra personnel and capacity in order to answer an exponentially increased number of telephone calls about the announced policy. Journalists seem to be more aware of market-related topics such as externalities and indirect costs and give more weight to the argument that CNAP can be a waste of time and money if intentions do not become law.

\section{Concerning Belgium (RQ4): Conditions CNAP}

Respondents were also asked under what circumstances the Government or ministers should be allowed to use CNAP. More specifically the following items were studied:

- the specific stage during the policy preparation;

- the type of media used; 
- the chance of parliamentary adoption;

- the aim of CNAP;

- any issue controversy;

- the criteria of CNAP.

Specific stage during the policy preparation. Regardless of the specific stage during the policy preparation, journalists as well as government communication professionals are very tolerant towards CNAP: Has the policy intention already been adopted by the government but not yet adopted by the Parliament or has the policy intention not yet been adopted by the government? Almost $93 \%$ of the journalists and $87.5 \%$ of government communication professionals take a favorable view of CNAP as long as the government gives its approval. Apparently, the parliamentary prerogatives are eroded. If the government has not yet adopted the policy intention, the number proponents of CNAP decreases noticeably $(65.5 \%$ of journalists, $68.8 \%$ of government communication professionals agree).

Type of media used. The views of Belgian journalists on the use of press briefings $(85.4 \%$ pro) and mass media campaigns $(7.3 \%$ pro) are in line with the opinion of government communication professionals. A difference in opinion emerges when each profession was asked whether individual public information from the government about CNAP (by telephone or e-mail) should be allowed. Half of the reporters take a positive view while only a third of government professionals are in favor ${ }^{2}$.

Chance of parliamentary adoption. When there is a reasonable chance that Parliament will approve policy intentions, journalists $(87.2 \%)$ as well as government communication professionals (78.2\%) say CNAP from ministers is permissible. When there is no reasonable chance of approval, however, government communication professionals are far more stringent (only $25 \%$ agree) than reporters (38.1\% agree).

Aims of CNAP. Pronounced differences between both professions arise when asked for the allowed aims of CNAP. Table 1 presents the statements where journalists tend to agree more than government communication professionals whereas Table 2 focuses on the opposite situation.

The (Belgian) journalists are twice as likely as the government communication professionals to have a favorable view on ministers who use CNAP to put policy topics on the political agenda (100\% and 53.3\% respectively). Remarkably, journalists are also more positive about CNAP as a way to force coalition partners to show their colors and to activate reluctant civil servants.

Increasing the legitimacy of a minister's actions is not an aim of CNAP generally supported by the (Belgian) journalists (34.6\%), even 
Table 1. Aims of CNAP on which journalists agree more than government communication professionals.

\begin{tabular}{llll}
\hline $\begin{array}{l}\text { Ministers can communication proactively } \\
\text { about CNAP in order to: }\end{array}$ & Journalists & $\begin{array}{l}\text { Government } \\
\text { communication } \\
\text { professionals }\end{array}$ & $\Delta$ \\
& $\begin{array}{l}\mathrm{N}=55 \\
(\%)\end{array}$ & $\begin{array}{l}\mathrm{N}=32 \\
(\%)\end{array}$ & $\begin{array}{l}\text { percent } \\
\text { points }\end{array}$ \\
\hline put the issue on the political agenda & 100.0 & 55.3 & 54.7 \\
force coalition partners to give their opinion & 85.4 & 62.8 & 22.6 \\
activate unwilling civil servants & 72.7 & 50.0 & 22.7 \\
check for public support & 92.7 & 77.4 & 15.3 \\
provoke action from significant others & 76.4 & 62.5 & 13.9 \\
mobilize target groups & 83.7 & 70.0 & 13.7 \\
\hline
\end{tabular}

Table 2. Aims of CNAP on which journalists agree less than government communication professionals.

\begin{tabular}{llll}
\hline $\begin{array}{l}\text { Ministers can communication proactively } \\
\text { about CNAP in order to: }\end{array}$ & Journalists & $\begin{array}{l}\text { Government } \\
\text { communication } \\
\text { professionals }\end{array}$ & $\Delta$ \\
& $\begin{array}{l}\mathrm{N}=55 \\
(\%)\end{array}$ & $\begin{array}{l}\mathrm{N}=32 \\
(\%)\end{array}$ & $\begin{array}{l}\text { percent } \\
\text { points }\end{array}$ \\
\hline $\begin{array}{l}\text { increase the legitimacy of their own action } \\
\text { counter contra arguments of opponents }\end{array}$ & 34.6 & 67.7 & -33.1 \\
$\begin{array}{l}\text { ameliorate their image } \\
\text { win votes }\end{array}$ & 25.6 & 75.0 & -20.4 \\
get a positive representation of policy & 30.9 & 56.3 & -30.8 \\
$\quad$ intentions in the media & 60.0 & 78.1 & -19.1 \\
$\begin{array}{l}\text { to prevent the policy process gets reversed } \\
\text { increase public support }\end{array}$ & 54.6 & 68.8 & -18.1 \\
hinder the policy process of others & 67.2 & 74.2 & -14.2 \\
\hline
\end{tabular}

though two thirds of government communication professionals hold a positive opinion $(67.7 \%)$. Another clear difference in opinion stands out when we look at the results on the statement 'Ministers can communicate proactively about CNAP in order to ameliorate their image'. The government communication professionals $(56.3 \%)$ are more than twice as likely to subscribe to this statement as the journalists $(25.5 \%)^{3}$. Opinion is not split over testing ideas before taking a final decision; journalists: $78.2 \%$, government communication professionals: $77.4 \%$. There does not appear to be a split over distracting attention from another topic (18.2 and $21.9 \%$ respectively).

Issue controversy. We asked to what extent respondents agreed with CNAP focusing on a controversial versus a non-controversial policy is- 
sue and whether this issue is a central governmental theme as mentioned in a general governmental policy agreement. Journalists and government communication professionals share the same view: $80 \%$ to $90 \%$ of the respondents are very positive with the exception of CNAP concerning controversial topics not belonging to the 'core' business of the government. Three quarters of the journalists questioned permitting CNAP on this subject while only half of the government communication professionals hold the same view.

Criteria of CNAP. We asked journalists and government communication professionals to rank a list of criteria important for CNAP: factuality, completeness, identification of source, consistency, competence, timeliness, and proportionality (in terms of budget and/or reach). This led to a ranking based on the value respondents ascribed to the different criteria, i. e., how many people attributed a specific place to a specific criterion was taken into account, and resulted in Table 3. Please note that the lower the value, the more important the criterion.

Table 3. Ranking criteria CNAP according to journalists and government communication professionals (the lower the value, the more important the criterion).

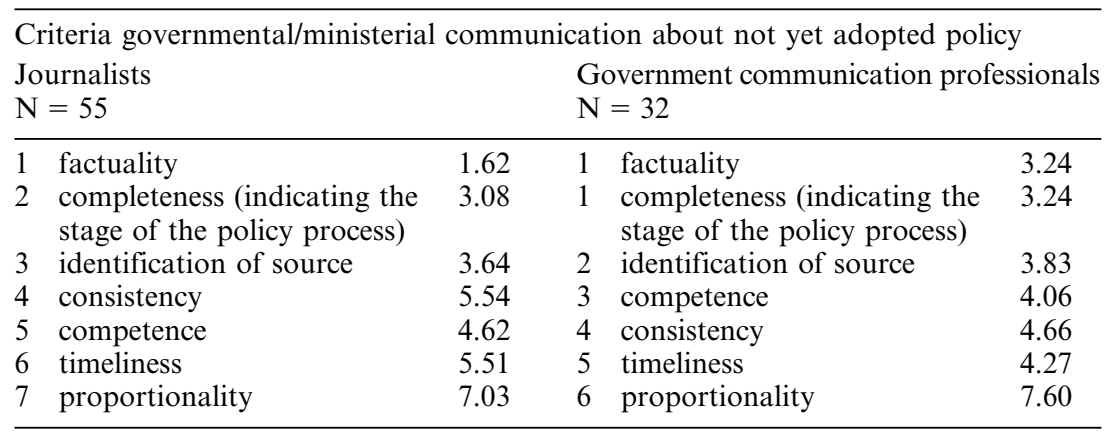

Presenting CNAP in a factual manner is ranked number 1 by both professions. The criteria of completeness and identification are also considered to be important. Although the ranking is identical, the specific values show journalists believe these criteria to be more important than government communication professionals do.

\section{Conclusion and discussion}

This article presented recent Belgian research data on government 'Communication about Not yet Adopted Policy' (CNAP), and it focused on the most relevant findings from Neijens' earlier research in the Netherlands. An elaborated comparison between the Dutch and the Belgian 
research is difficult as the Belgian studies consider CNAP more into detail, while the Dutch research also dealt with other topics than CNAP.

One should keep in mind that the research methodology differed in some perspectives, especially regarding the scale of population, as well as the technique used (printed/electronic survey versus face-to-face interviews). Consequently, it cannot be excluded that possible differences in research results between the Netherlands and Belgium, as well as between Belgian government communication professionals and journalists are (partly) due to differences in research methodology. However, most of the Dutch journalists Neijens questioned were political journalists' comparable to the Belgian journalists Lahousse asked for their opinion. The socio-demographic data of both the journalists and government communication professionals correspond in both countries.

Our research shows that government communication about as of yet unadopted policy is generally accepted. This implies that the professionals involved - journalists as well as government communication professionals - are positive towards new government information guidelines such as of the Dutch Committee on the Future of Government Communication (CTO 2002). The research results confirm that the frontiers between the formal political process on the one hand and those of the informal forum of the media on the other have been diffused (Seydel, Prins, Serikei, and Van Twist, 2002), and that the parliamentary prerogatives have been eroded (Dewachter, 2001). It proves that the news media are the platform where the government establishes or loses its credibility and that the battle for the public's trust increasingly takes place in the media rather than in the parliament (Brants, 2000).

An important difference between the opinion of journalists and government communication professionals is that journalists are especially positive towards the openness related to CNAP (e. g., agenda setting, checking public support). They are less positive towards the possibilities of CNAP to influence (e.g., increase legitimacy, improve own image). Government communication professionals are positive about the latter objectives.

Based on our research we can formulate three recommendations for further study. First, our empirical study focused on the manner in which journalists and government communication professionals consider CNAP 'acceptable'. Less attention could be paid to another important issue, namely the extent to what CNAP is 'opportune'. Further research could focus on this aspect. Secondly, it is useful to conduct large-scale content analyses to messages coming from ministers or other political leaders. This may shed new light on the current manner in which ministers or political leaders actually communicate about policy intentions, and this may indicate the extent to what these politicians follow the 
criteria for good CNAP, as ranked by the respondents. Last but not least, this article presented recent Belgian data on the opinion of professionals towards CNAP. Where possible, we compared these data to earlier Dutch research that did not questioned CNAP in detail. This creates problems of comparability. However, in other countries empirical research on this issue is completely non-existing. It would be useful to conduct a large-scale comparative research to the opinions of journalists, government communication professionals, politicians and citizens regarding government communication about policy intentions.

\section{Notes}

1. http://www.vlaanderen.be/overheidscommunicatie

2. Compared to the guidelines of the Dutch Commission on Future Government Communication (CTO, 2002), the less stringent outlook on CNAP by the Dutch stands out. The Commission stipulates that it is absolutely reasonable that the government can use all information channels in the formulation stage of policymaking.

3. When compared to the Dutch findings, both Belgian professions are strikingly less stringent than Dutch journalists (only $12 \%$ agree) and government communication professionals ( $40 \%$ agree). Nevertheless, a considerable difference between both professions remains in both countries. The latter appears to have a dissimilar outlook on the aims of government communication. This cleavage is also shown by the results on the question whether CNAP should be allowed to gain voters: journalists hold a less favorable view (only $30.9 \%$ agree) than government communication professionals ( $50 \%$ agree). Increasing public support for an issue is seen as a legitimate use of CNAP by government communication professionals in Belgium ( $74.2 \%)$ and in the Netherlands $(93 \%)$ whereas reporters see it as a less legitimate use (Belgium: $67.2 \%$, the Netherlands: $50 \%$ ).

\section{References}

Blumler, J. and Gurevitch, M. (1995). The crisis of public communication. London: Routledge.

Brans, M. and Hondeghem, A. (1999). The senior civil service in Belgium. In E. Page and V. Wright (Eds.), In bureaucratic elites in West European state. Oxford: Oxford University Press.

Brants, K. (2000). Double bind. The ambivalent relationship between politics and the media. Inaugural lecture. University of Leiden.

Cappella, J. and Jamieson, K. (1997). The spiral of cynicism. New York: Oxford University Press.

Cobb, R. and Elder, C. (1981). Communication and public policy. In D. Nimmo and K. Sander (Eds.), Handbook of political communication. Bevery Hills, CA: Sage.

Cook, C., Heath, F. and Thompson, R. (2000). A meta-analysis of response rates in web-or internet-based surveys. Educational and Psychological Measurement, 60(6), $821-836$.

CTO [Commission on Future Government Communication] (2002). In dienst van de democratie [In service of democracy]. Den Haag: Sdu. 
De Bens, E., De Clercq, M. and Paulussen, S. (2003). Het profiel van de Vlaamse beroepsjournalist [The Profile of the Dutch-speaking professional journalist in Belgium]. De Journalist, (59), 4-11.

Delano, A. and Henningham, J. (1995). The news breed: British journalists in the 1990s. London: School of Media.

Delorme, D. and Fedler, F. (2003). Journalists' hostility toward public relations: A historical analysis. Public Relations Review, 29(2), 99-124.

Deuze, M. (2002). National news cultures: Towards a profile of journalists using crossnational survey findings. Journalism Quarterly, 79(1), 134-149.

Dewachter, W. (2001). De mythe van de parlementaire democratie: Een Belgische analyse [The myth of the parliamentary democracy: A Belgian analysis]. Leuven: Acco.

Gelders, D. (2005a). Public information provision about policy intentions: the Dutch and Belgian experience. Government Information Quarterly, 22(1), 75-95.

Gelders, D. (2005b). Communicatie over nog niet aanvaard beleid: Een uitdaging voor de overheid? [Communication about as of yet unadopted policy: A challenge for government?]. Unpublished Doctoral dissertation, University of Leuven, Belgium.

Henningham, J. (1996). Australian journalists' professional and ethical values. Journalism Quarterly, 73(1), 206-218.

Jempson, M. (2005). Spinners or sinners? PR, journalists and public trust. Journal of Communication Management, 9(3), 267-276.

Kranendonk, S. (2003). BOR: bereikbaarheidsoffensief of rekeningrijden? De slag om het bereikbaarheidsoffensief en het rekeningrijden. De invloed van de geschreven pers op publieke steun [Toll roads in the Netherlands: The influence of the printed press on public support]. Amsterdam: Scriptie VUAmsterdam.

Lahousse, E. (2005). Externe communicatie over nog niet aanvaard beleid: Rol van de media [External communication about as of yet unadopted policies: The role of the media]. Unpublished master's thesis, University of Leuven, Belgium.

Linsky, M. (1986). Impact: How the press affects federal policymaking. New York: Norton.

Mazzoleni, G. and Schultz, W. (1999). 'Mediatization' of politics: a challenge for democracy? Political Communication 16(3), 247-261.

McChesney, R. (1999). Rich media, poor democracy: communication politics in dubious times. Urbana. IL: University of Illinois Press.

Meyer, T. (2002). Media democracy: How the media colonize politics. Cambridge: Polity Press.

Neijens, P. (2002). Actieve communicatie over niet-aanvaard beleid: De kloof tussen overheidscommunicatie en journalistiek. [Active communication about not accepted policy: The gap between government communication and journalism] Tijdschrift voor Communicatiewetenschap, 30(4), 279-294.

Norris, P. (2000). The virtuous circle, Cambridge: Cambridge University Press.

Patterson, T. (1993). Out of order. New York: Vintage Books.

Patterson, T. (1996). Bad news, bad governance. The Annals of the American Academy of Political and Social Science, 546, 97-108.

Scammell, M. (1999). Political marketing: Lessons for political science. Political Studies, 43(4), 718-739.

Seydel, E, Prins, G., Serkei, C., and Van Twist, M. (2001). Vitale ontwikkelingen in het medialandschap en de gevolgen voor de overheidscommunicatie. Bijlage bij rapport in dienst van de democratie [Vital developments in the media and implications for government communication. Annex report in service of democracy]. Den Haag: Sdu.

Stappers, J. and Nillessen, B. (1985). Voorlichters in informatieverschaffers onderzocht. Voorlichters doorgelicht. Massacommunicatie, 13(5), 186-199. 
Stegall, S and Sanders, K. (1986). Coorientation of pr practitioners and news personnel in education news. Journalism Quarterly, 63, 341-393.

Suetens, M. and Walgrave, S. (1999). Leven en werk van de kabinetsleden. Wie zijn de mannen achter de minister en wat doen ze? [Life and work of the ministerial personal cabinet assistants. Who are the man behind the minister and what do they do?]. Res Publica: Journal of Political Science, 41(4), 499-528.

Swanson, D. and Mancini, P. (Eds.) (1996). Politics, media and modern democracy. London: Praeger.

Van Ruler, B. (1996). Communicatiemanagement in Nederland: Een verkenning naar de visie van communicatiemanagers op de inhoud van hun beroep [Communication management in the Netherlands: An exploration of the vision of communication managers on the content of their profession]. Houten: Bohn Stafleu Van Loghum.

Van Ruler, B. (1995). De perceptie van journalisten en voorlichters van eigen en andermans beroep. Overpeinzingen over de relatie tussen voorlichting en journalistiek [The perception of journalists and government communication professionals of their own profession and the profession of the other [Reflections on the relationship between public information provision and journalism]. In G. Jilleba et al. (Eds.), Jaarboek overheidscommunicatie [Yearbook government communication]. 's Gravenhage: Vereniging voor Overheidscommunicatie.

Weischenberg, S., Loeffelholz, M., and Scholl, A. (1998). Journalism in Germany. In D. H. Weaver (Ed.), The global journalist: Studies of news people around the world (pp. 229-256). Creskill, NJ: Hampton Press. 